\title{
Evolution of the Large Scale Circulation, Cloud Structure and Regional Water Cycle Associated with the South China Sea Monsoon during May-June, 1998
}

\author{
K.-M. LAU \\ Laboratory for Atmospheres, NASA / Goddard Space Flight Center, Greenbelt, MD, USA \\ Xiaofan LI \\ NOAA/NESDIS, Office of Research and Applications, Camp Springs, MD, USA \\ and \\ H.T. WU \\ Science System Application Inc., Lanham, MD, USA \\ (Manuscript received 21 March 2000, in revised form 11 May 2002)
}

\begin{abstract}
This paper studies the evolution of the South China Sea (SCS) monsoon during May-June 1998, to elucidate relationships among the large scale circulation, organization of convection, cloud structures, and fluctuations of the regional water cycle of the SCS. Primary data used include field observations from the South China Sea Monsoon Experiment (SCSMEX), and the satellite rain products from the Tropical Rainfall Measuring Mission (TRMM). Prior to the onset of the SCS monsoon, enhanced convective activities associated with the Madden and Julian Oscillation were detected over the equatorial Indian Ocean in early May while the SCS was under the influence of the West Pacific Anticyclone with prevailing low level easterlies and suppressed convection. Subsquently, a bifurcation of the MJO convection near $90^{\circ} \mathrm{E}$ led to the development of strong convection over the Bay of Bengal, which spawned low-level westerlies across Indo-China and contributed to the initial build-up of moisture and convective available potential energy over the northern SCS. The onset of the SCS monsoon occurred around May $18-20$, and appeared to be triggered by the equatorward penetration of extratropical frontal disturbances, originating from the continental regions of East Asia.

Analysis of TRMM microwave and precipitation radar data revealed that during the onset phase, convection over the northern SCS consisted of squall-type rain cells embedded in meso-scale complexes similar to extratropical systems. The radar Z-factor intensity indicated that SCS clouds possessed a bimodal distribution, with a pronounced signal $(>30 \mathrm{dBz})$ at a height of $2-3 \mathrm{~km}$, and another one $(>25 \mathrm{dBz})$ at the $8-10 \mathrm{~km}$ level, separated by a well-defined melting level signaled by a bright band at around 5-km level. The most convectively active phase of the SCS monsoon, as measured by the abundance of convective and stratiform hydrometeor types, inferred from the radar vertical profile, was found to occur when the large scale vertical wind shear was weakest.
\end{abstract}

Corresponding author: William K.-M. Lau, Cli-

mate and Radiation Branch, Laboratory for Atmospheres, Code 913, NASA/GSFC, Greenbelt, MD 20771, USA.

E-mail: lau@climate.gsfc.nasa.gov

(C) 2002, Meteorological Society of Japan 
The fluctuation of the water cycle over the northern SCS was found to be closely linked to the largescale dynamical and SST forcings. Before onset and during the break, the northern SCS was relatively warm and served as a moisture source $(E-P>0)$ to the overlying atmosphere. During the active phase, the northern SCS was cooled, providing a strong sink $(E-P \ll 0)$ for atmospheric moisture, with the primary source of moisture coming from regions further west over Indo-China and the eastern Indian Ocean. Vigorous water recycling by convective systems in the northern SCS occurred during the mature phase of the SCS monsoon, with precipitation efficiency (defined as the ratio of the surface precipitation to the sum of large scale moisture convergence and surface evaporation from the ocean) approaching 96\%. Westward transport of moisture from Indo-China into, and northward transport out of, the northern SCS provided the main source of moisture for the torrential rain over the YRV in mid-June 1998. The present results suggest that the SCS may play an important role in regulating the SCS monsoon active and break cycles through charge and discharge of moisture, and convective available potential energy.

\section{Introduction}

The Asian monsoon commences each year around mid-May over the South China Sea (SCS) and Indo-China region (Tao and Chen 1987; Lau and Yang 1997; Lau et al. 1998; Hsu et al. 1999). Climatologically, the rainy season over southern China and northern SCS begins in late April or early May in conjunction with the development of quasi-stationary frontal systems (Chang and Chen 1995). The sudden onset of the SCS monsoon is signaled by a large-scale wind shift in the lower troposphere from easterly to westerly, and outburst of deep convection over the SCS (Lau et al. 1998; Ding et al. 1999; $\mathrm{Li}$ and $\mathrm{Qu}$ 1999). Convective activities in the vicinity of northern SCS and the Philippines have been linked to interannual and intraseasonal rainfall variability over mainland China and Japan, as well as summertime teleconnection signals over the North Pacific (Nitta 1987; Huang and Sun 1992; Lau and Peng 1992; Chen et al. 2000; Lau and Weng 2000a, b). Since precursory signals of anomalous monsoons over East Asia and South Asia can often be detected early in the season (Lau and Yang 1997), understanding the physical processes of onset and maintenance of SCS convection is critically important for predicting possible occurrence of droughts and floods in the Asian monsoon land regions.

However, because of the lack of frequent and reliable observations over the SCS, much of the physical processes leading to onset, break and variability of the SCS monsoon remain unknown. For example, it is not clear how convective systems in the SCS are organized with respect to the changes in the large-scale environment? How much of the water available for
SCS convection is derived from local evaporation, and how much from transport outside the SCS? How does the SCS monsoon relate to variability of other sub-components of the Asian monsoon, i.e., the Bay of Bengal depression, onset of the Indian monsoon and abrupt changes in the Mei-yu in East Asia?

Thanks to the availability of field data from the South China Sea Monsoon Experiment (SCSMEX) in the summer of 1998, and satellite rainfall products from the Tropical Rainfall Measuring Mission (TRMM), answers to these questions are now possible (Lau et al. 1999). In this paper, we will carry out a diagnostic study to shed light on some of the above questions. The objective of this paper is to provide a description of the changes of the large-scale circulation, and their relationships with changes in structure of rainfall and convective systems, and the regional water cycle. Because early versions of SCSMEX and TRMM data are used in this study, results presented here, especially the quantitative estimates of various parameters, can only be considered as tentative. The use of high-resolution reanalysis data from the GEWEX Asian Monsoon Experiment (GAME), which merges SCSMEX and GAME data, and in combination with the latest version of TRMM data should provide more reliable quantitative estimates and validation of the present results in future studies.

\section{Data}

Observations from SCSMEX include enhanced soundings from stations and ships, dual Doppler radars, aerosondes, surface flux measurements from ships and buoys, and satellitederived ocean surface wind and rain products 
from TRMM and scatterometer. Details of the observational platforms, data description, and preliminary results have been reported in Lau et al. (1999). For the analysis of the large-scale circulation and regional water budget calculations, we used analyzed wind and moisture data from the SCSMEX soundings (Johnson et al. 1999). The wind data has horizontal and vertical resolutions of $2^{\circ} \times 2^{\circ}$ and $25 \mathrm{mb}$, respectively. Scatterometer wind at $10 \mathrm{~m}$ derived from SSM/I data (Atlas et al. 1996) was used to extend the SCSMEX domain to include the Indian Ocean and the western Pacific. The TRMM satellite has provided the surface rain rate and vertical profile of hydrometeors over the entire tropics between $40^{\circ} \mathrm{S}$ and $40^{\circ} \mathrm{N}$ since November 1997 (Kummerow et al. 2000; Oki et al. 1998). Also used are daily mean rain rate from (2A12), constructed from TRMM Microwave Imager (TMI) surface rain rate with the horizontal resolution of $0.5^{\circ} \times 0.5^{\circ}$, TMI sea surface temperature (SST) with $0.25^{\circ} \times 0.25^{\circ}$ resolution, and reflectivity (2A25) from the TRMM precipitation radar (PR), with vertical resolution of $250 \mathrm{~m}$ and horizontal resolution of $5 \mathrm{~km}$.

\section{SCS monsoon onset and large scale evolution}

\subsection{Tongsha Island observations}

The timing of evolution of the SCS summer monsoon during May-June 1998 is well captured by the surface observations (Fig. 1) at Dongsha Island which is located at $117^{\circ} \mathrm{E}, 21^{\circ} \mathrm{N}$ in the northern SCS (denoted by the symbol $\Delta$ in Fig. 2a). The surface wind at the site fluc-
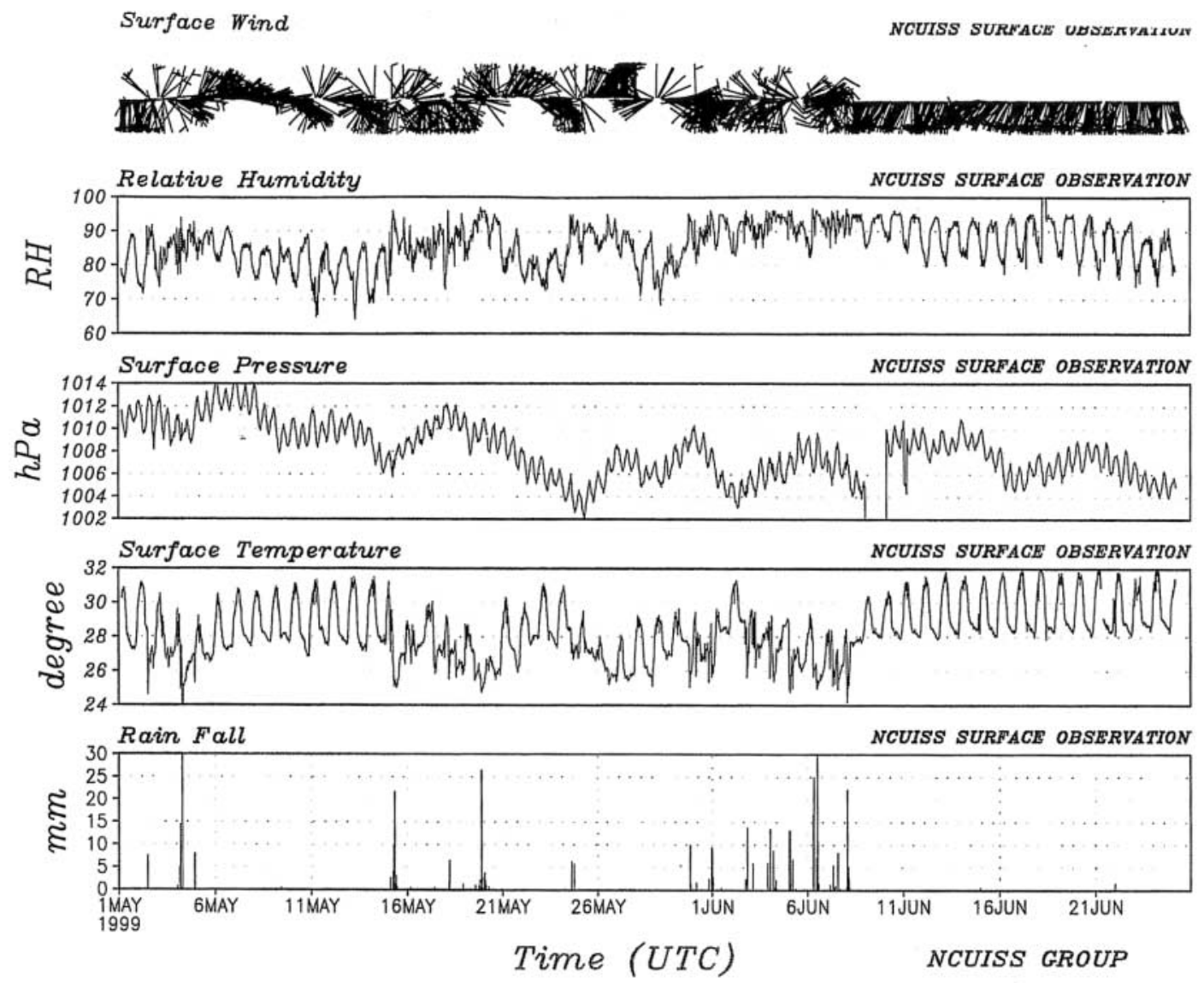

Fig. 1. Time series of surface wind vector $(\mathrm{m} / \mathrm{s})$, relative humidity $(\%)$, surface pressure $(\mathrm{mb})$, surface temperature $\left({ }^{\circ} \mathrm{C}\right)$, and rainfall $(\mathrm{mm})$ observed at Dongsha Island during May-June 1998 (Courtesy of Prof. P.L. Liam, National Central University). 
tuated between northeasterly to southwesterly during the entire month of May due to development of a quasi-stationary front over the region (Chang and Chen 1995). The monsoon onset was signaled by sudden shifts in fluctuation regimes in relative humidity, surface pressure and surface temperature. Before May 16, pronounced diurnal cycles were observed. After May 16, as the SCS monsoon got underway, the diurnal cycles were diminished, accompanied by rising relative humidity, falling surface pressure and temperature. The periods when the diurnal cycles of surface temperature over Dongsha Island were pronounced coincided with the pre-onset and the break phases of the SCS monsoon, when clear sky conditions prevailed over the northern SCS. During these periods, insolation can reach the ground and produce a pronounced diurnal cycle in surface ground and air temperature. The rain gauges at Dongsha also recorded generally enhanced rainfall during the active monsoon period (May 16-June 8). Sporadic heavy rain episodes found in early and mid-May can be attributed to influence from extratropical frontal systems (see discussions in next section). The active monsoon conditions abruptly ceased around June 8, after which the rain stopped, the diurnal cycles resumed, and the surface wind turn steady southerlies during June 12-21, signaling a break in the SCS monsoon. As shown later, the monsoon break coincided with the advance of the monsoon trough to the East Asian continent, and the development of the Mei-yu rain band over the Yangtze River Valley (YRV), which began around the second week in June 1998.

\subsection{Large scale evolution}

Figures 2 and 3 show the time evolution of the large-scale surface wind derived from SSM/ I and rain rate from TRMM Goddard Profiling algorithm (GPROF) during the period encompassing the onset of the SCS monsoon and the occurrence of heavy rainfall over the YRV. During the early part of May (Fig. 2a), the West Pacific Anticyclone (WPA) dominated the large-scale circulation pattern over the subtropical western Pacific from equator to $35^{\circ} \mathrm{N}$. Clear sky and strong easterly winds prevailed over the western tropical Pacific, and the SCS on May 14 and thereabout. A quasi-stationary pre-monsoon front system was developed and anchored over southeastern China and Taiwan at the northwestern rim of the WPA (Fig. 2b). At this time, convection was notably intense over the Indian Ocean, where a large-scale anticyclonic gyre circulation was emerging. The intense convection over the Indian Ocean could be traced back to convection that occurred over the coast of eastern Africa about a week earlier (see Fig. 4a and accompanying discussion). The convective complex can be identified with the supercloud cluster associated with the Madden and Julian Oscillation (MJO) (Nakazawa 1988; Lau et al. 1991). The MJO signature was evident in a pair of cyclones straddling the equator on both hemispheres, which were especially pronounced on May 14 (Fig. 2b, and discussion in Section 3c). Shortly afterwards, the frontal system intensified and began to move southeastward as the WPA retreated eastward.

The eastward shift of the WPA was accompanied by the strengthening of equatorial westerlies over the Indian Ocean as the MJO intensified and propagated eastward. On May 18 (Fig. 2c), the MJO double cyclone bifurcated away from the equator in both hemispheres. The southern cyclone eventually dissipated, while the northern cyclone propagated northeastward and developed into a major monsoon depression over the Bay of Bengal (BB) around May 18-20. The vertical wind profile over the central SCS (not shown here, see Fig. 4 in Lau et al. 1999) indicated that the entire tropospheric wind system developed a strong easterly shear (low level westerly and upper level easterlies) around May 18-20, signaling the onset of the SCS monsoon. During the onset phase, low level westerly and southwesterly winds developed over the entire SCS, as the frontal system swept southeastward into the tropical western Pacific (Fig. 2d). Frequent outbreak of deep convection occurred over the SCS west of the Philippines during the active phase of the SCS monsoon, from May 20-June 8 (Fig. 2e, f). The sequence of events were remarkably similar to that observed in May 1997 (Lau et al. 1998).

At the end of the active period (June 5-9), the frontal rain band was re-established over the northern SCS, with pronounced southerly flow over the SCS (Fig. 3a). At this time, the India monsoon was about to begin, as indicated 

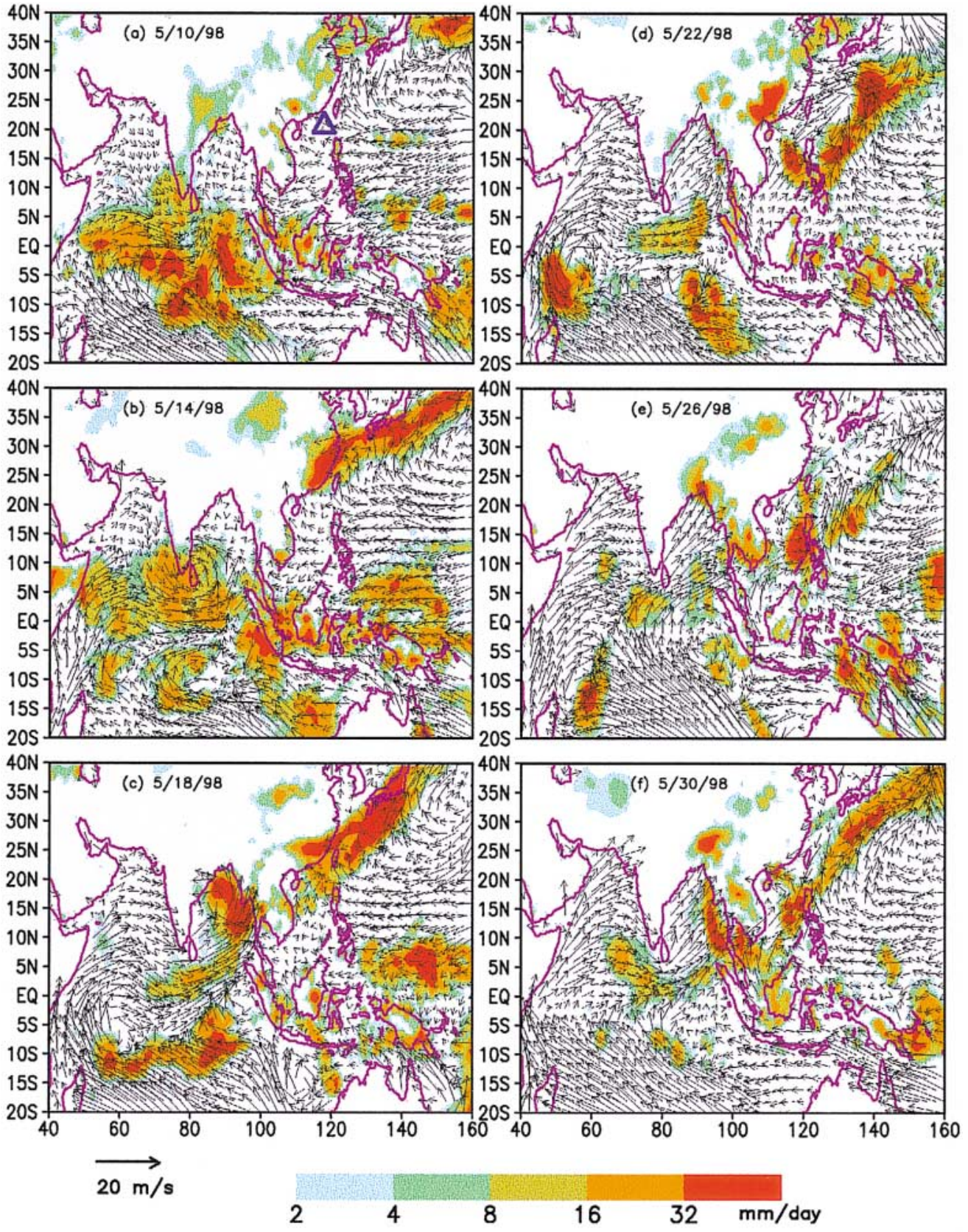

Fig. 2. Daily-mean surface rain rate from TRMM GPROF and surface wind from SSM/I for May 10$30,1998$.

by the onset of heavy rain near the west coast of the Indian subcontinent, and the establishment of the Indian Ocean gyre circulation. By June 9 (Fig. 3b), the WPA had fully retreated eastward, and a monsoon depression was redeveloped over the BB. Strong low-level southerlies over the SCS continued to transport moisture throughout the break period from the SCS into southern China. The strong and steady southerly flow pushed the monsoon trough poleward, leading to the establishment of the Mei-yu front, and torrential rainfall over the YRV beginning June 13 (Fig. 3c). From June 17-21 the monsoon rain band vascillated 


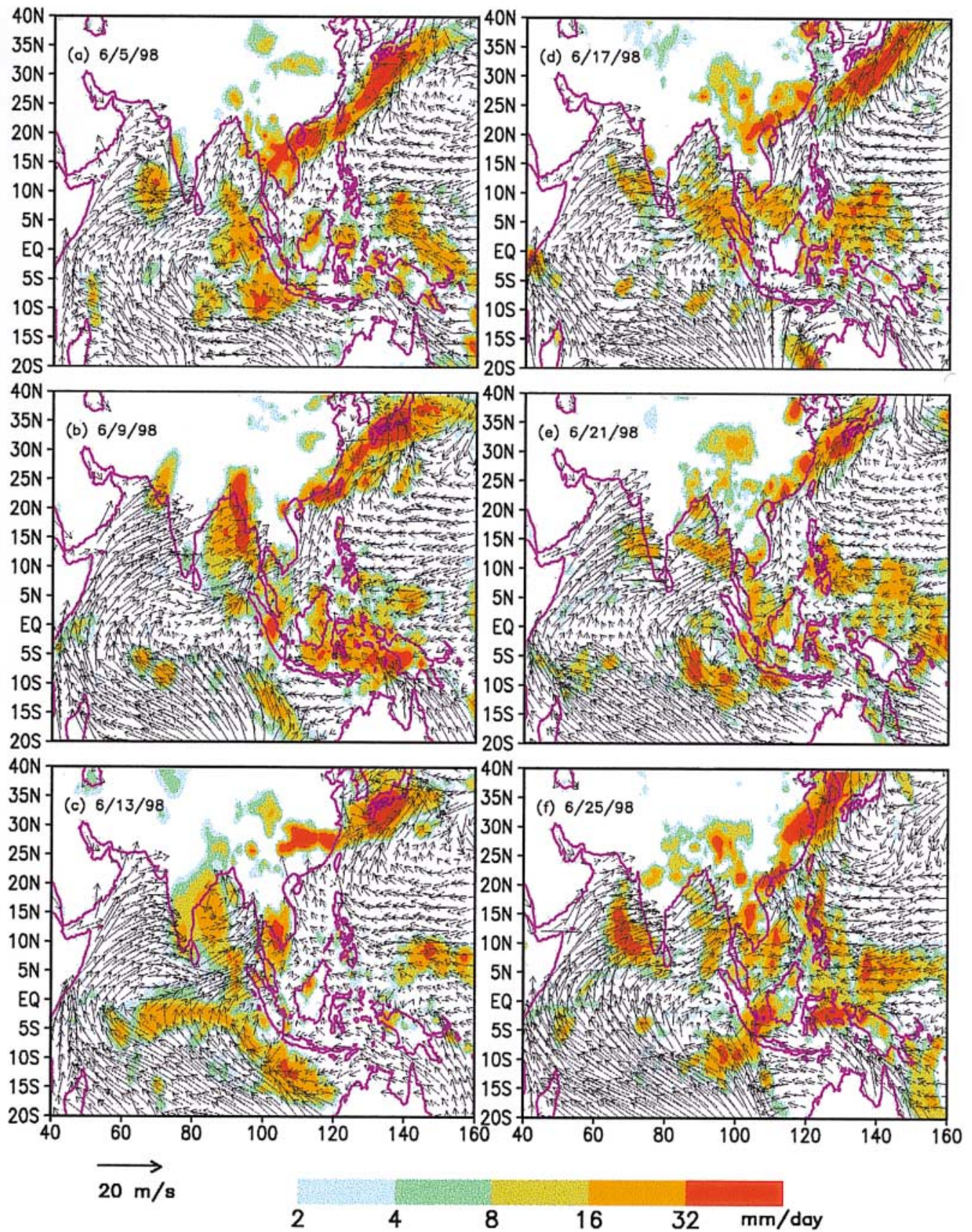

Fig. 3. Same as Fig. 2, except for June 5-25, 1998.

between the YRV and southern China, causing widespread flooding in the region. The SCS region remained quiescent during that period (Fig. 3d and e). After June 21, the SCS monsoon was revived, as indicated by the reappearance of deep convection over the SCS (Fig. 3f).

\subsection{Intraseasonal variability}

In this subsection, we provide a description of the MJO and related signals in the context of the onset and evolution of the SCS monsoon. During the 1997-98 ENSO cycle, MJO activities in the Indo-Pacific regions were very pronounced (McPhaden 1999). The characteristic 


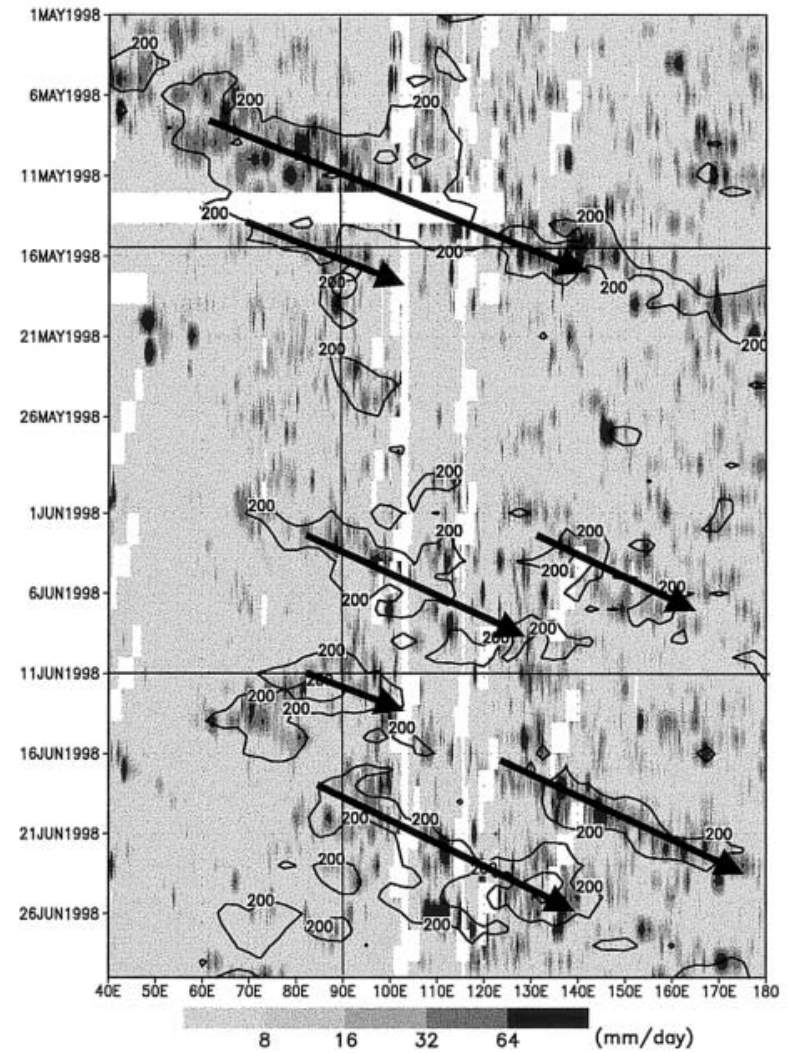

(a)

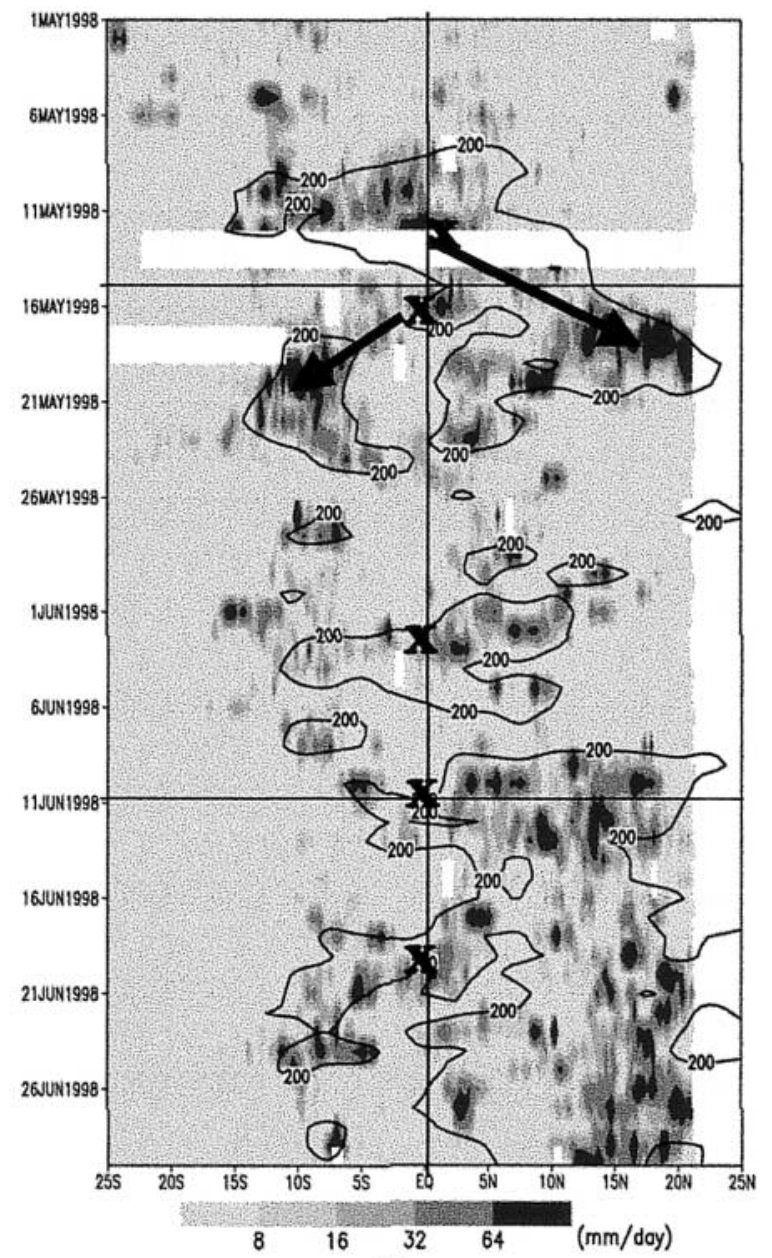

(b)

Fig. 4. (a) Time-longitude cross-section of daily TMI rainrate and OLR $\left(<200 \mathrm{Wm}^{-2}\right)$ averaged over $10^{\circ} \mathrm{S}-10^{\circ} \mathrm{N}$ across the Indo-Pacific region. The line arrows indicate a propagation speed of approximately $8 \mathrm{~m} \mathrm{~s}^{-1}$. (b). Same as in Fig. 4a, except for the time-latitude cross-section of TMI and OLR averaged between $85-90^{\circ} \mathrm{E}$. The X's mark the time of crossing of the eastward propagating MJO signal at $90^{\circ} \mathrm{E}$ along the equator.

eastward propagation of the MJO attaining speed of approximately $8 \mathrm{~m} / \mathrm{s}$, is evident in the time-longitude sections of TMI daily rainfall along the equator (Fig. 4). Most of the heavy precipitation $(>32 \mathrm{~mm} /$ day $)$ were confined within the $200 \mathrm{Wm}^{-2}$ Outgoing Longwave Radiation (OLR) contour, which formed an envelope of the MJO supercloud cluster (Nakazawa 1988; Lau et al. 1991). By far the MJO occurring in May was the most pronounced and persistent during SCSMEX-98, having the associated supercloud clusters propagating all the way from the western Indian Ocean to the dateline and beyond. It had been suggested that this MJO might have caused the abrupt termination of the 1997-98 El Niño, ushering in the 1998-99 La Niña (Takayabu et al. 1999). Figure 4 shows that the MJO convective system arrived at the equatorial SCS $\left(110-120^{\circ} \mathrm{E}\right)$ around May 15-16, coinciding with the abrupt drop in surface temperature in Dongsha (see Fig. 1 and related discussion). Subsequently, the source region of the MJO convection shifted to the central Indian ocean near $70^{\circ} \mathrm{E}$. From May 16 to June 11, when the SCS monsoon was active, the MJO activities along the equator 
subsided considerably. From June 11 to the end of the month, the MJO became active again, mostly over the eastern equatorial ocean and the western Pacific.

As noted in Fig. 2, besides eastward propagation along the equator, the MJO was also associated with meridional propagation, and excitation of convection away from the equator. Figure $4 \mathrm{~b}$ shows that when the eastward propagating signal of the first $\mathrm{MJO}$ reached $90^{\circ} \mathrm{E}$ around May 12-13 (marked by the uppermost $\mathrm{X})$, it spawned north and south migrations of deep convective systems away from the equator. The northern branch eventually evolved into deep convection, associated with the explosive development of the BB depression around May 18-19 $\left(\sim 15-20^{\circ} \mathrm{N}\right)$. As noted previously, the $\mathrm{BB}$ convection is followed in one or two days by the outburst of deep convection over the South China Sea, east of the Philippines (see Fig. 2d). The arrival of subsequent MJOs near $90^{\circ} \mathrm{E}$ (marked by X's in Fig. $4 \mathrm{~b}$ ), appeared to excite convection on both sides of the equator, with major activities in the summer monsoon region north of the equator. The bifurcation of deep convection around $90^{\circ} \mathrm{E}$, in relation to the onset of the Asian monsoon, has been noted in a number of recent studies of SCSMEX (Lau et al. 1999, 2000) and reports from the JASMINE experiments (Webster 2001, private communication). It is worth noting that monsoon convection in the region $90^{\circ} \mathrm{E}-120^{\circ} \mathrm{E}$, $10^{\circ} \mathrm{N}-25^{\circ} \mathrm{N}$ is strongly modulated by irregular cycles of 10-20 days, in addition to the 30-60 day timescale associated with the MJO, as evident in Fig. 4. These cycles may be related to the interaction of 12-24 day oscillations with the MJO (30-60 days) during the evolution of the SCS monsoon (Chen and Chen 1995)

In the discussion of Fig. 2, we noted the frontal structure of the convective system in southern China, and northern SCS as indications of a possible immediate triggering of the SCS monsoon onset. This is evident in the time-latitude sections of TMI rainfall, and $850 \mathrm{mb}$ zonal wind along $108-122^{\circ} \mathrm{E}$ shown in Fig. 5a and b. The low level zonal winds follow the movement of the monsoon trough and is a measure of the low level jet associated with the development of the Mei-yu front in the subtropics (Chen and Chang 1980; Chu and Chen 1996). The southward propagation of disturbances form the ex-

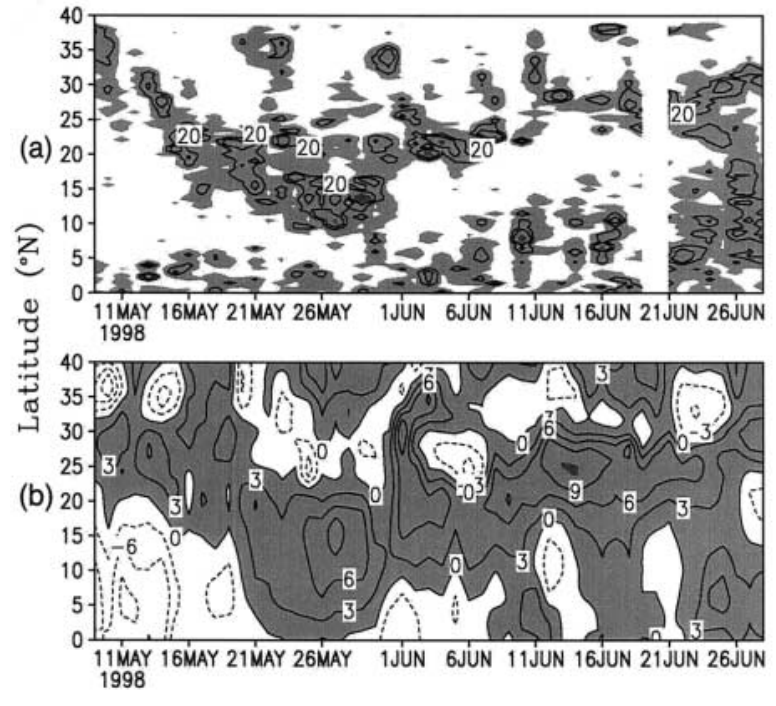

Fig. 5. Time-latitude section of daily variations of (a) $850 \mathrm{mb}$ zonal wind, and (b) TRMM rainfall, averaged between 110$120^{\circ} \mathrm{E}$.

tratropics, evident in the low level $850 \mathrm{mb}$ and in the TMI rainfall during May 10-20, was initiated before the onset of the SCS monsoon, which can be placed at somewhere between May 16-22, depending on the definition used (see discussion in Section 4). After May 25, when the SCS monsoon was fully developed, the heavy rain system propagated northward, reaching the Yangtze River Valley (YRV, 25$30^{\circ} \mathrm{N}$ ) around June 12, where it remained stationary until June 22. Subsequently, the rain system pushed further northward. The strong YRV rainfall coincided with the break of the SCS monsoon, when the SCS region $\left(15-20^{\circ} \mathrm{N}\right)$ was dry and the monsoon flow featured a steady southerly low-level flow over the northern SCS. As will be shown later, these southerlies were crucial in supplying moisture to the YRV convection.

\section{Composite analyses}

\subsection{Reference time series}

Figure 6 shows the time series of areaaveraged TRMM rain rate over the SCS (10$\left.24^{\circ} \mathrm{N}, 108-122^{\circ} \mathrm{E}\right)$, the $\mathrm{BB}\left(11-15^{\circ} \mathrm{N}, 84-98^{\circ} \mathrm{E}\right)$ and the YRV $\left(24-38^{\circ} \mathrm{N}, 116-130^{\circ} \mathrm{E}\right)$ respectively. Clearly seen are the gradual building up 


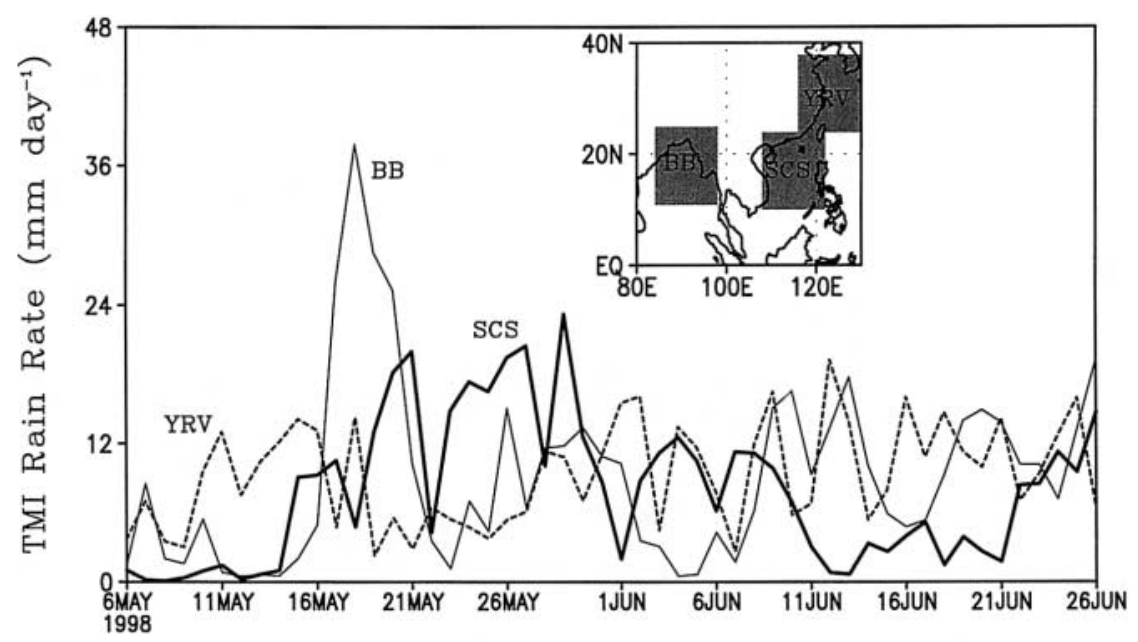

Fig. 6. Time series of TMI daily surface rain rates $\left(\mathrm{mm} \mathrm{day}^{-1}\right)$ averaged over the SCS (solid line) and over the Yangtze River area (dashed line).

of convection over the SCS beginning May 15, the establishment of the BB convection around May 16-18, followed by its decay in a few days, and the build up of heavy rain over the SCS. By far, the BB convection was most intense with maximum rain rate exceeding $36 \mathrm{~mm} /$ day, while the SCS and YRV had comparable rain rates with maximum at approximately 22$24 \mathrm{~mm} /$ day. The YRV rainfall also appeared to vary somewhat inversely with that over the SCS, with enhanced activity during the early part of May and throughout most of June. For the purpose of quantifying the intensity and structural changes in convection and for computing the regional water budget, we defined four different phases of the evolution of the large scale SCS monsoon as: pre-onset phase (May 914), onset phase (May 15-22), active phase (May 23-June 11), and break phase (June 1221). These dates were chosen based on the major shifts in the large-scale circulation and rainfall over the SCS as discussed previously. Because the onset of the SCS monsoon was progressive, the exact days marking the different phases may vary depending on the choice of parameters and/or geographical locations (e.g., Chen et al. 2000 and Ding et al. 1999).

\subsection{Kinematics}

Figure 7 shows the horizontal distributions of time-mean TMI surface rain rates, winds and divergences at 200 and $850 \mathrm{mb}$ based on the SCSMEX wind analysis, for representative pentads within the four phases of the SCS summer monsoon respectively. The area mean values of the key dynamical quantities over the SCS region referred to in the following discussion can be found in Table 1 . The pre-onset phase was characterized by suppressed convection (Fig. 5a, upper panel) and widespread subsidence over the SCS, as indicated by the negative divergence at $200 \mathrm{mb}$, and positive divergence at $850 \mathrm{mb}$. The WPA was fully extended westward, prevailing over the entire SCS and the Indo-China region. Over the land mass of East Asia, active mid-latitude disturbances were evident in a pronounced $200 \mathrm{mb}$ jetstream, strong $200 \mathrm{mb}$ divergence (middle panel), and $850 \mathrm{mb}$ convergences and cyclonic activities (lower panel). While rainfall was light, with area mean of approximately $1 \mathrm{~mm} /$ day, the convective available potential energy, $\left(\mathrm{CAPE} \sim 1.69 \times 10^{3} \mathrm{Jkg}^{-1}\right.$ ) over the SCS during the pre-onset was the highest among the four phases.

During the onset phase (Fig. 7b), deep convection as indicated by heavy rain cells developed along a southwest-northeast swath from the BB, across Indo-China to the East China Sea (upper panel). The area mean rain rate increased to $11 \mathrm{~mm}$ day $^{-1}$. The convection over the northern SCS was associated with equatorial penetration of an extratropical front coming from central East Asia, as evident in the 
(a) Pre-onset
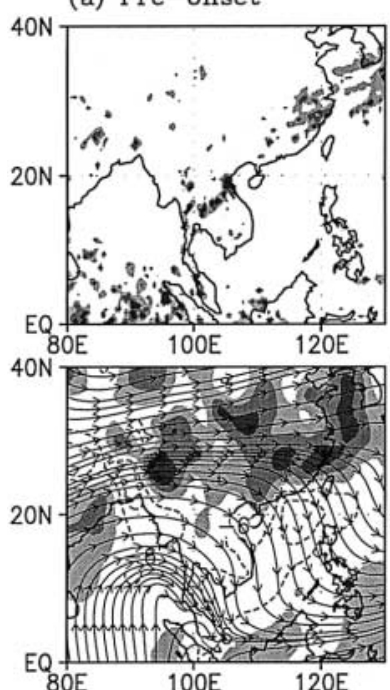

(b) Onset

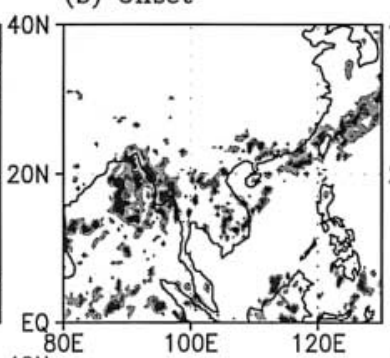

(c) Active

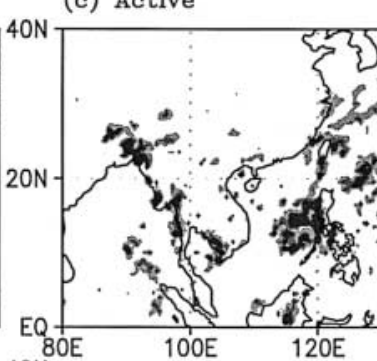

(d) Break

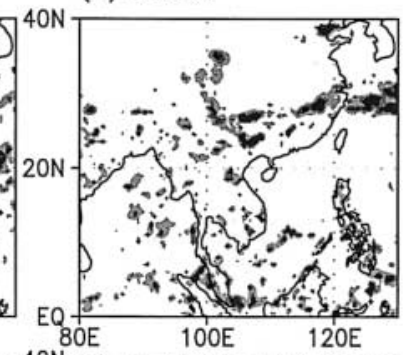

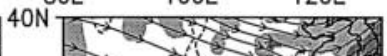
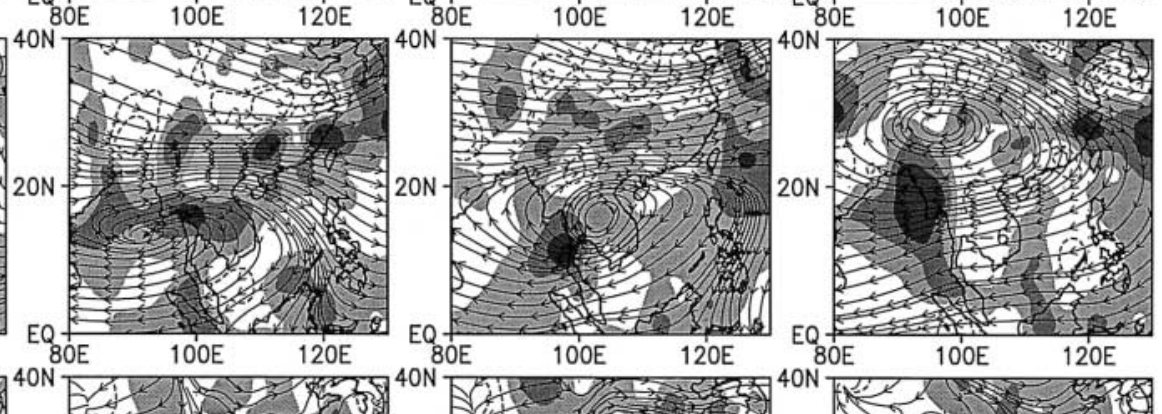

$80 \mathrm{E}$

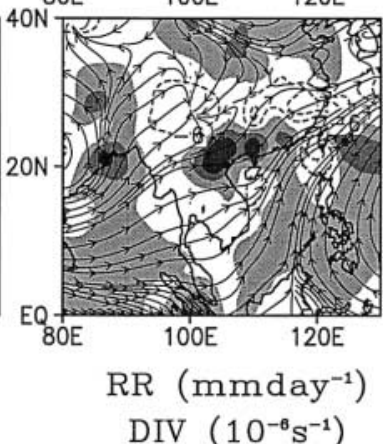

DIV $\left(10^{-6} \mathrm{~s}^{-1}\right)$

Fig. 7. Horizontal distributions of pentad mean TMI surface rain rates (upper panel), streamline and divergence $\left(10^{-6} \mathrm{~s}^{-1}\right)$ at $200 \mathrm{mb}$ (middle panel) and at $850 \mathrm{mb}$ (lower panel). The pentads are chosen to represent the (a) pre-onset, (b) onset, (c) active and (d) break phases.

Table 1. Areal mean dynamical characteristics over the SCS during different stages of the SCS monsoon as defined in the text.

\begin{tabular}{|c|c|c|c|c|c|c|}
\hline & $\begin{array}{l}200 \mathrm{mb} \text { Div } \\
\left(10^{-5} \mathrm{~s}^{-1}\right)\end{array}$ & $\begin{array}{l}500 \mathrm{mb} \text { Div } \\
\left(10^{-5} \mathrm{~s}^{-1}\right)\end{array}$ & $\begin{array}{l}850 \mathrm{mb} u \\
\left(\mathrm{~ms}^{-1}\right)\end{array}$ & $\begin{array}{l}\text { Precipitation } \\
\left(\mathrm{mm} \mathrm{day}^{-1}\right)\end{array}$ & $\begin{array}{l}\text { CAPE } \\
\left(10^{3} \mathrm{~J} \mathrm{~kg}^{-1}\right)\end{array}$ & $\begin{array}{l}\text { Zonal wind } \\
\text { vertical shear } \\
\left(\mathrm{ms}^{-1}\right)\end{array}$ \\
\hline $\begin{array}{l}\text { Pre-onset } \\
(5 / 9-5 / 13)\end{array}$ & -0.61 & 0.17 & -2.0 & 1.12 & 1.69 & 8.5 \\
\hline $\begin{array}{l}\text { Onset } \\
(5 / 15-5 / 19)\end{array}$ & 0.17 & -0.09 & 0.20 & 11.09 & 1.38 & 14.3 \\
\hline $\begin{array}{l}\text { Active } \\
(5 / 25-5 / 29)\end{array}$ & 0.22 & -0.16 & 4.0 & 25.88 & 1.18 & -3.0 \\
\hline $\begin{array}{l}\text { Break } \\
(6 / 14-6 / 18)\end{array}$ & -0.19 & 0.06 & 3.5 & 2.99 & 1.61 & 15.5 \\
\hline
\end{tabular}

southward shift of the $200 \mathrm{mb}$ jetstream, and the development of pronounced low level southwesterly flow over southern China and Taiwan. The complex of heavy rain cells over the Bay of
Bengal was associated with the development of a strong monsoon depression, as indicated by the $200 \mathrm{mb}$ anticyclone (middle panel) and the $850 \mathrm{mb}$ cyclone (lower panel) over the region. 
Over the SCS, positive divergence at $200 \mathrm{mb}$ $\left(\sim 0.17 \times 10^{-5} \mathrm{~s}^{-1}\right)$ coupled with convergence at $850 \mathrm{mb}\left(\sim-0.09 \times 10^{-5} \mathrm{~s}^{-1}\right)$ implied upward motion, and a favorable environment for initiation of deep convection. The flaring up of convection over the SCS, mostly triggered by squall-type frontal systems led to partial release of CAPE $\left(\sim 1.38 \times 10^{3} \mathrm{Jkg}^{-1}\right)$, amounting to $20 \%$ reduction of CAPE from its pre-onset or build-up phase.

During the active phase, deep convection became more frequent over the SCS, with heavy rain cells anchored to the west of the Philippines (Fig. 7c, upper panel). The upper level anticyclone over Indo-China was fully developed with the westerly jet found at the southernmost position, near $20^{\circ} \mathrm{N}$ (middle panel). Concomitantly, the WPA was fully retracted eastward, and low level westerly wind with averaged speed of $\sim 4-5 \mathrm{~ms}^{-1}$ blew from the eastern Indian Ocean across Indo-China to the SCS (lower panel). The divergence at upper troposphere and the convergence at the lower troposphere peaked during this period (see Table 1). Rainfall over the SCS was heaviest $\left(\sim 27 \mathrm{~mm} \mathrm{day}^{-1}\right)$, and the CAPE was at its lowest $\left(\sim 1.18 \times 10^{3} \mathrm{Jkg}^{-1}\right)$, approximately a $30 \%$ reduction from the onset phase. This energy was presumably released into kinetic energy in driving the SCS monsoon.

During the break phase, deep convection mostly vanished over the SCS, and a zonally oriented frontal system established over the YRV near $30^{\circ} \mathrm{N}$ (Fig. 7d, upper panel). The mean rain rate dropped to approximately $3 \mathrm{~mm}$ day $^{-1}$. At this stage, the upper level westerly jet was re-established at $35-40^{\circ} \mathrm{N}$, and a pronounced anticyclone developed downstream of the Tibetan Plateau (middle panel). Over the SCS, the upper level convergence $(\sim 0.19 \times$ $\left.10^{-5} \mathrm{~s}^{-1}\right)$ at $200 \mathrm{mb}$, and low-level divergence $\left(\sim 0.06 \times 10^{-5} \mathrm{~s}^{-1}\right)$ at $850 \mathrm{mb}$, indicated the resumption of large-scale subsidence, and a rebuild up of CAPE $\left(\sim 1.61 \times 10^{3} \mathrm{JKg}^{-1}\right)$ over the region. Strong southerly wind $\left(\sim 5.1 \mathrm{~m} \mathrm{~s}^{-1}\right)$ over the SCS and southwesterly wind from Burma and southwestern China converged into the Mei-yu front over the YRV.

\subsection{Cloud structure}

Changes in cloud structure, and rain systems associated with the four stages of the SCS monsoon will be discussed in this section. Figure 8 shows a snapshot of TMI surface rain rate, corrected $Z$ factor (PR reflectivity) at 2.5$\mathrm{km}$ level, and vertical cross section of PR $Z$ factor along $16.5^{\circ} \mathrm{N}$ and $17^{\circ} \mathrm{N}$ on May $20,1998$. Associated with the southward penetration of the frontal rain band, multiple heavy rain cells oriented in the southwest-northeast direction were formed (Fig. 8, upper left). Embedded with the heavy rain cell, the PR data indicated a meso-scale complex with squall-line structure including deep convective cores at the leading edge, with trailing stratiform clouds (Fig. 8, upper right). The size of the deep convective cores in the leading edge (represented by contours of the $Z$ factor higher than $40 \mathrm{dBz}$ ) was not larger than $20 \times 20 \mathrm{~km}^{2}$. The trailing stratiform region $(>30 \mathrm{dBz})$ spanned an area of approximately $50 \mathrm{~km}$ to $100 \mathrm{~km}$.

The vertical structure (Fig. 8, lower panel) provided a snapshot of complex convective processes within the mesoscale system. As indicated by coincident ground radar echo (Tom Keenan, private communication), the convective complex was moving southwestward at the time of the snapshot. At the leading (western) portion of the system, a developing convective chimney and a dying convective element, were detected. The leading convective chimneys $(>40 \mathrm{dBz})$ reached to about $5 \mathrm{~km}$, and upper level stratiform cirrus anvil $(>20 \mathrm{dBz})$ developed up to $10 \mathrm{~km}$ in the vicinity of the convective core. In between the leading cell and the main cell, is a region of reduced reflectivity, where downdraft was likely to be prevalent. The main cell possessed a spatial scale of about $100 \mathrm{~km}$, within which strong convective activity $(>40 \mathrm{dBz})$ appeared to be maintained over a large horizontal fetch at the $5 \mathrm{~km}$ level, which coincided with the melting level for tropical convection. This suggested that the main cell was in its mature development being maintained by vigorous microphysical and mesoscale processes in the middle and upper troposphere. Further separated from the main cell was a trailing convective cell, probably near the end of its life cycle.

Because of the lack of spatial and temporal sampling of the PR data, individual convective events cannot be tracked. Here, we used a composite method to delineate the possible changes in convective and cloud structures as- 

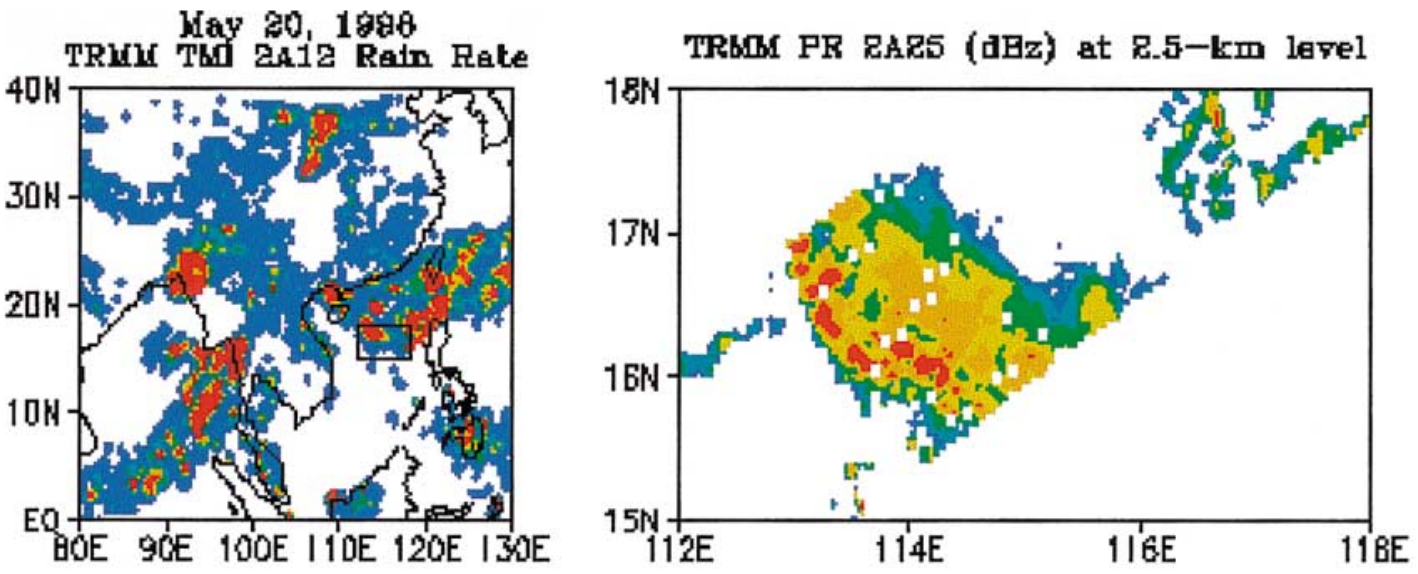

TRHW PR 2AR5 (dB2) alang 18.5\%N
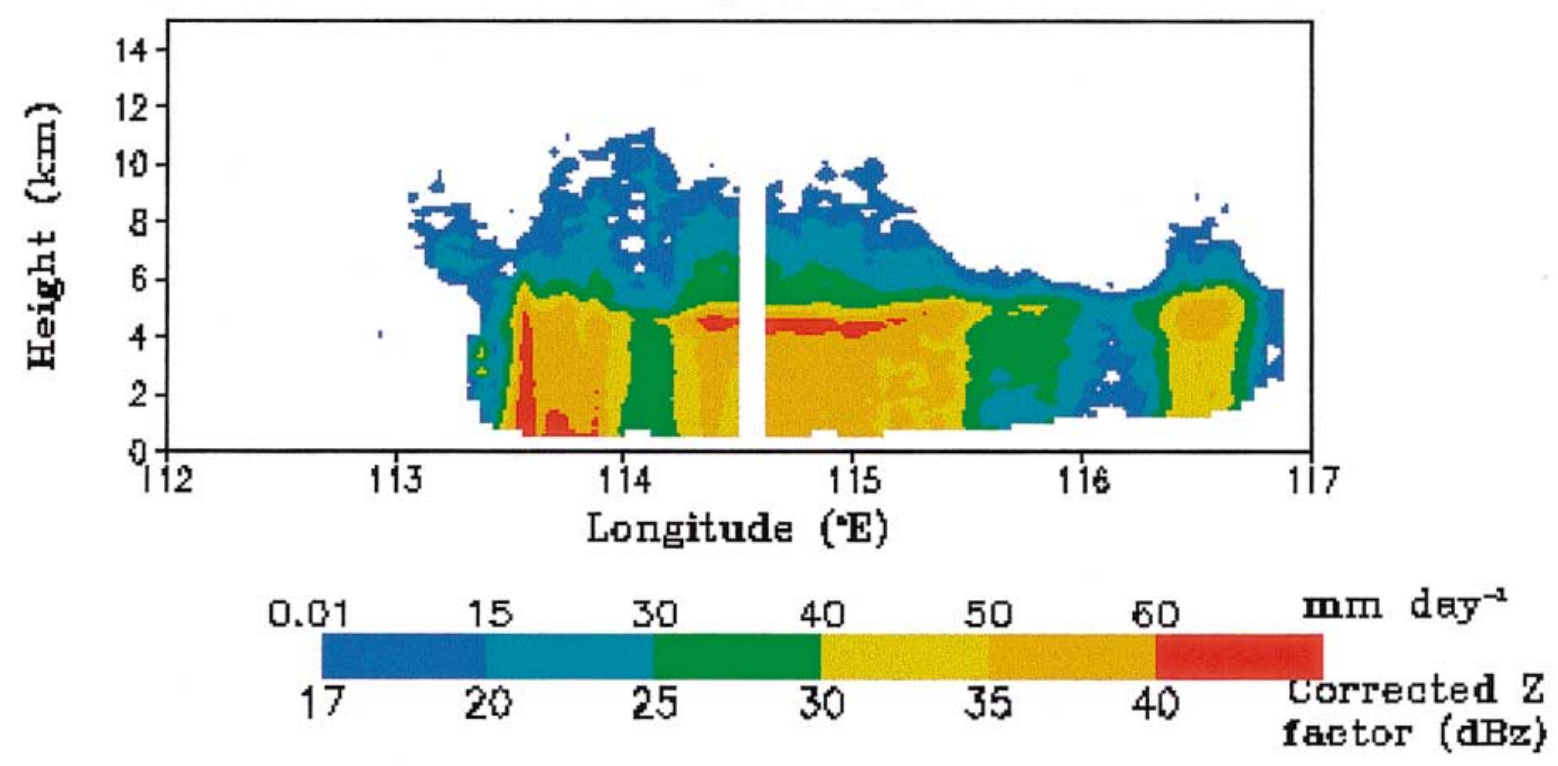

Fig. 8. Horizontal distribution of TMI derived surface rain rate (upper left panel) and PR corrected Z factor at 2.5-km level (upper right panel), and vertical cross section of corrected $\mathrm{Z}$ factor along $16.5^{\circ} \mathrm{N}$ (lower panel) on 20 May 1998.

sociated with different stages of the SCS monsoon. Figure 9 shows the probability distribution functions for the PR data as a function of height and PR values, also known as Contoured Frequency Altitude Diagram (CFAD, Yuter and Houze 1995). Here contour values represent the percentage of occurrences for a given range of $P R$ values and altitude that fell with the spatial and temporal domain for the SCS monsoon stages.

During the pre-onset phase (Fig. 9a), only weak signals were detected below the melting level $(\sim 5 \mathrm{~km})$. Water clouds associated with shallow convection covered about $1-2 \%$ of the total SCS area, with a maximum at $2-\mathrm{km}$ level. During the monsoon onset phase (Fig. 7b), the CFAD assumed a distinct bimodal distribution centered around $30 \mathrm{dBz}$ and altitude of 2$4 \mathrm{~km}$, and $20 \mathrm{dBz}$ at $6-10 \mathrm{~km}$, with a clear separation at approximately $5.5 \mathrm{~km}$. The first mode was associated with deep convective cores, consisting of water clouds below the freezing level $(\sim 5-5.5 \mathrm{~km})$ covering $2-4 \%$ of total area, while the second mode indicated developing stratiform anvils and ice clouds above the melting level, with approximately $3-5 \%$ 
(a) Pre-onset

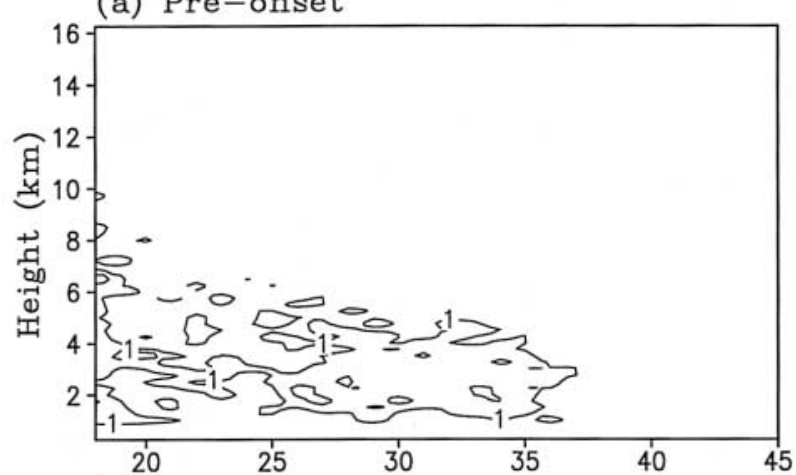

(b) Onset

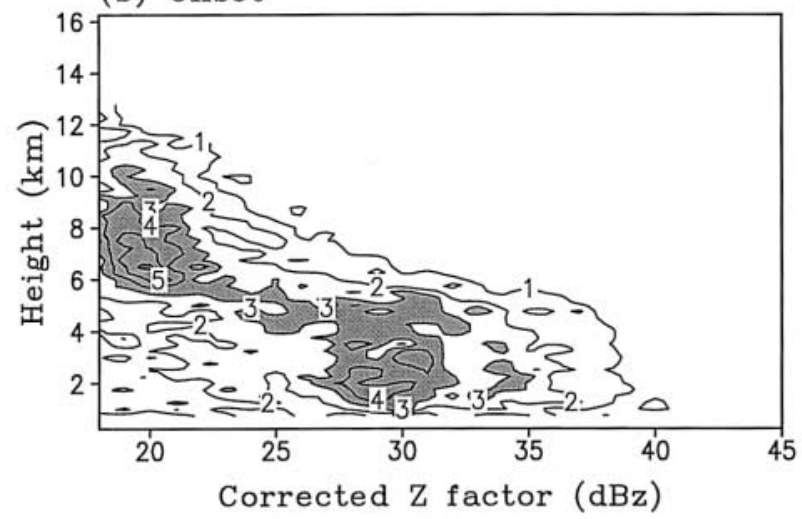

(c) Active

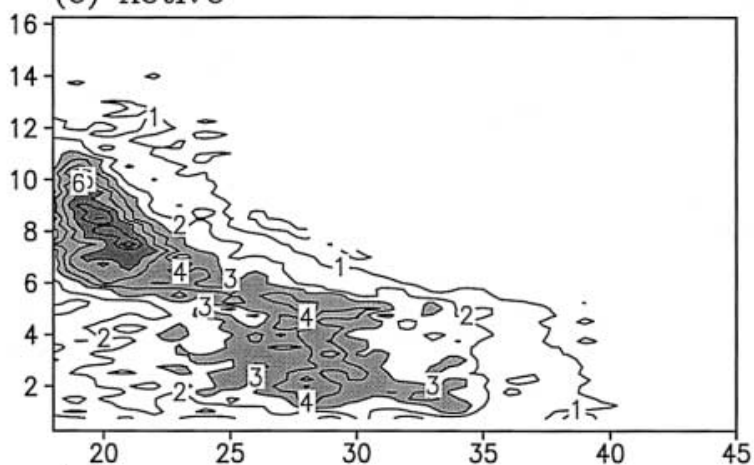

(d) Break

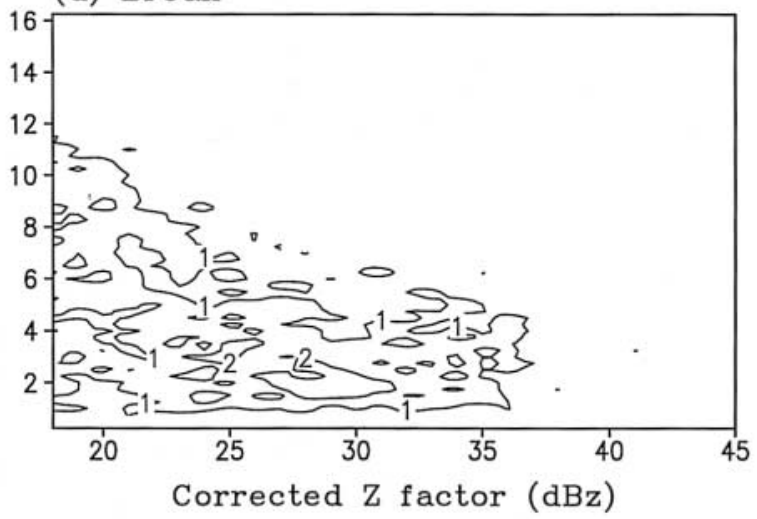

Fig. 9. Vertical distributions of probability distribution functions of PR Corrected Z factor over the northern SCS during (a) pre-onset, (b) onset, (c) active, and (d) break phases of the SCS monsoon.

coverage. In the active phase (Fig. 9c), the CFAD was basically similar to the onset phase, showing an increased frequency of occurrence of both convective and stratiform cloud types. The stratiform cloud showed more substantial increase, with the $20 \mathrm{dBz}$ signal reaching above $10 \mathrm{~km}$. The bright band at the melting level near $5.5 \mathrm{~km}$ was well-defined indicating the active conversion process within vigorous convective systems. The maximum stratiform population increased to over $6 \%$, and the convective fraction remained at $4 \%$. During the break (Fig. 9d), the CFAD was similar to the pre-onset phase, with mostly low-level water clouds. Some weak signals were found above the melting level, probably due to remnants of upper level clouds generated from deep convection during the mature phase. It is interesting to note that the increase in convective activity, as measured by the abundance of stratiform and convective clouds during active phase was associated with the reduction in large-scale vertical wind shear (zonal mean wind difference between $200 \mathrm{mb}$ and $850 \mathrm{mb}$, shown in Table 1, last column) over the SCS region, which went from $14.3 \mathrm{~ms}^{-1}$ in the onset phase, to $-3.0 \mathrm{~ms}^{-1}$ in the active phase. During the break phase, the strong wind shear magnitude $\left(=15.5 \mathrm{~ms}^{-1}\right)$ may have also contributed to the inhibition of convection both of the stratiform and convective types

As a comparison, the CFAD for the Mei-yu cloud systems over the YRV region $\left(25-35^{\circ} \mathrm{N}\right.$, $116-128^{\circ} \mathrm{E}$ ) before and during the development of the torrential rain was shown in Fig. 10. The former was within the active phase, and the latter coincided with the break phase of the SCS monsoon. The structure changes of the Mei-yu cloud systems shown in Fig. 8a and b indicated a near reversal of those between the mature and the break phases of the SCS monsoon shown in Fig. 9c and d. While the anvil cloud distribution during YRV heavy rain was similar to the active SCS cloud system, the 
(a) Pre-YRV
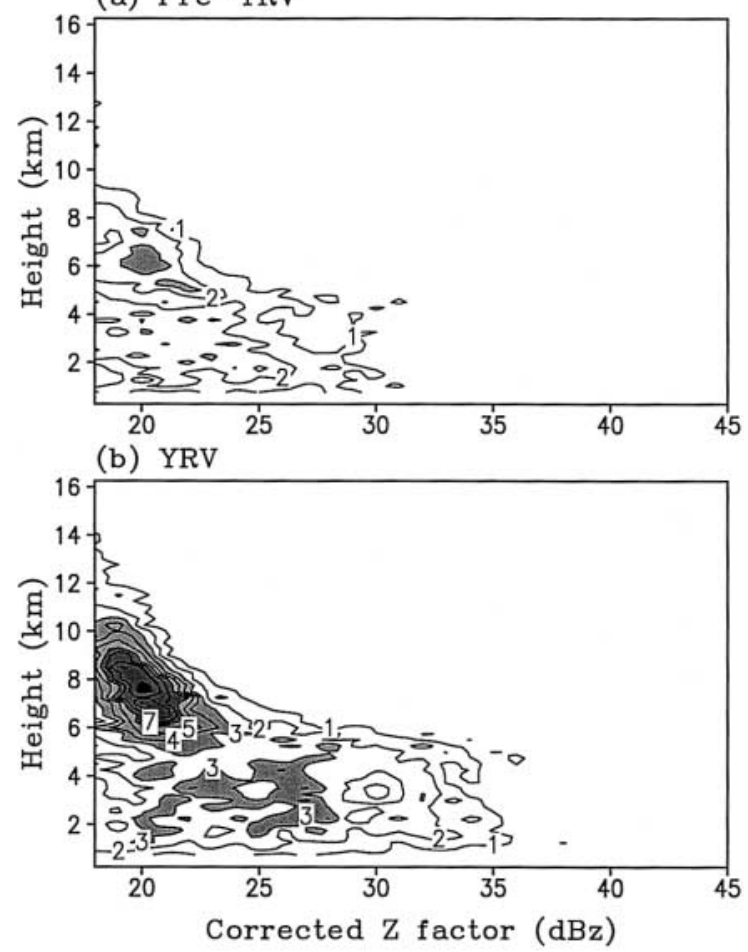

Fig. 10. As in Fig. 9 except over the Yangtze River area for (a) pre-heavy rain and (b) during heavy rain periods in June 1998.

signal below the melting level was lesser pronounced compared with the SCS clouds. The difference suggested that mid-latitude processes, i.e., stratiform clouds associated with frontal development, may be more important for sustaining the Mei-yu system during 1998. The vertical wind shear appeared to be always higher than the SCS systems, with magnitude of $22-23 \mathrm{~ms}^{-1}$ respectively, during the preYRV and the YRV phases, as typical of extratropical systems. However, the relationship between YRV cloud types from TRMM PR, and the vertical wind shear is not clear.

\section{Regional water cycle}

In the section, we examine the variations of the water budget over the SCS in relation to the large scale circulation changes and SST forcings during different phases of the SCS monsoon. Here we focus on the northern SCS which is situated at the junction of large- scale influences from the Indian Ocean, the western Pacific and the East Asian continent. The total columnar water budget is computed over the northern SCS area $\left(8-24^{\circ} \mathrm{N}, 108-\right.$ $122^{\circ} \mathrm{E}$ ), shown as a rectangular box in Fig. 11. The total moisture tendency (TMT), the net moisture convergence (NMC), precipitation $(P)$, and surface evaporation $(E)$ are governed by the following water vapor conservation equation:

$$
\frac{\partial\langle q\rangle}{\partial t}+\nabla \cdot\langle q V\rangle=E-P,
$$

where $\langle>$ denotes vertical integral from the earth surface to the top of the atmosphere. The first and second terms on the left hand side of (1) denote the total moisture tendency (TMT) and the net moisture convergence (NMC) respectively. Summing over the entire domain, (1) becomes:

$$
\begin{aligned}
\mathrm{TMT} & =\mathrm{NMC}-P+E, \\
\mathrm{NMC} & =F_{S}-F_{N}+F_{W}-F_{E},
\end{aligned}
$$

where $F_{N}, F_{S}, F_{W}$ and $F_{E}$ represent the mean contribution to the net moisture convergence by fluxes across the north, south, west and east boundaries of the domain respectively. TMT and NMC were computed by using the SCSMEX sounding data, and $E-P$ computed as the residual. The estimated values of all the terms in (2) for different phases of the SCS monsoon were shown in Table 2a. As a measure of the intensity of the hydrologic cycle with respect to the large-scale forcings, we have also computed (shown in the last column of Table 2) the large scale precipitation efficiency, defined as the ratio of the total rainfall to the total available moisture $(\mathrm{NMC}+E)$.

During the pre-onset phase, NMC was negative, consistent with the prevailing low-level divergence over the northern SCS. Due to suppressed convection and clear sky conditions favored by large scale subsidence, a warm pool (SST $>30^{\circ} \mathrm{C}$ ) began to develop over the SCS region (Fig. 11a). The northern SCS region gained moisture (=1.4 units, with one unit equal to $10^{13} \mathrm{~kg}$ day $^{-1}$ ) from the western $\mathrm{Pa}$ cific through the eastern boundary, as a result of prevailing surface easterlies from the WPA, while transporting a large portion (=3.1 units) to the land region, to the north. There was a 
Table 2a. Estimate of the various terms in the water budget (in unit of $10^{13} \mathrm{Kg}_{\text {day }}{ }^{-1}$ ) over the SCS region.

\begin{tabular}{|l|l|l|l|l|l|l|l|l|}
\hline & TMT & NMC & $\mathrm{F}_{\mathrm{N}}$ & $\mathrm{F}_{\mathrm{S}}$ & $\mathrm{F}_{\mathrm{W}}$ & $\mathrm{F}_{\mathrm{E}}$ & $\mathrm{E}-\mathrm{P}$ & $\begin{array}{l}\text { Precipitation } \\
\text { efficiency }\end{array}$ \\
\hline $\begin{array}{l}\text { Pre-onset } \\
(5 / 9-5 / 13)\end{array}$ & 0.3 & -1.6 & 3.1 & -0.1 & 0.2 & -1.4 & 1.9 & $50 \%$ \\
\hline $\begin{array}{l}\text { Onset } \\
(5 / 15-5 / 19)\end{array}$ & 0.4 & 1.1 & 1.0 & 0.5 & 2.1 & 0.5 & -0.7 & $87 \%$ \\
\hline $\begin{array}{l}\text { Active } \\
(5 / 25-5 / 29)\end{array}$ & 0.2 & 3.2 & 0.6 & 0.6 & 5.3 & 2.1 & -3.0 & $96 \%$ \\
\hline $\begin{array}{l}\text { Break } \\
(6 / 14-6 / 18)\end{array}$ & 0.1 & -0.7 & 4.3 & 1.9 & 3.0 & 1.4 & 0.8 & $47 \%$ \\
\hline
\end{tabular}

Table 2b. As in Table 2a, except for water budget over the YRV region.

\begin{tabular}{|l|l|l|l|l|l|l|l|l|}
\hline & TMT & NMC & $F_{\mathrm{N}}$ & $\mathrm{F}_{\mathrm{S}}$ & $\mathrm{F}_{\mathrm{W}}$ & $\mathrm{F}_{\mathrm{E}}$ & E - P & $\begin{array}{l}\text { Precipitation } \\
\text { efficiency }\end{array}$ \\
\hline $\begin{array}{l}\text { Pre-YRV } \\
(5 / 20-5 / 24)\end{array}$ & 0.3 & 0.0 & 0.9 & -1.0 & -1 & -0.9 & 0.3 & N/A \\
\hline $\begin{array}{l}\text { YRV } \\
(6 / 14-6 / 18)\end{array}$ & 0.0 & 3.8 & 0.2 & 4.1 & 5.4 & 5.5 & -3.8 & $101 \%$ \\
\hline
\end{tabular}

net moisture divergence out of the region, indicating that the northern SCS served as a net moisture source to the overlying atmosphere $(E-P>0)$. The precipitation efficiency was rather low at $50 \%$, and the atmosphere was being moistened (TMT $>0$ ), primarily by surface evaporation, because NMC was negative. At this juncture, the CAPE was at its peak, indicating that the atmosphere over the SCS was being charged up for convective instability. During the onset phase, the northern SCS region gained moisture, mainly from low level westerly flow spun off from the BB convection via the western boundary (=2.1 unit), transporting about half of the amount (=1.0 unit) to the land region further north. Here, the total moisture was building up at a rate of 0.4 units, and the SST over the northern SCS continued to rise, with the warmest water found just west of the Philippines (Fig. 11b). Deep convection over the northern SCS occurred more frequently, as indicated by the increase in precipitation efficiency to $85 \%$. The increasing atmospheric low-level moisture, and the warmer SST underneath, created a convectively unstable environment. As shown previously, the outburst of organized deep convection in the northern SCS is probably triggered by the incursion of a frontal system from south China into the northern SCS. The increase in precipitation efficiency is consistent with the reduction in CAPE, i.e., conversion of convective potential energy to kinetic energy of the monsoon flow, during the onset phase.

In the active phase, all the transport into the northern SCS came from the western boundary $(=5.3$ units $)$, with a substantial fraction $(=2.1$ units) coming out of the eastern boundary into the western Pacific. Here, the budget numbers indicate about $60 \%$ of the precipitation was derived from the east-west transport, and $40 \%$ from the surface evaporation over the northern SCS. The precipitation efficiency was very high, with $96 \%$ of the total available water from moisture convergence and surface evaporation deposited as surface rain in the northern SCS. In response to the strong monsoon flow and increased convection, the northern part of the SCS cooled rapidly. Strong low-level monsoon southwesterlies caused coastal upwelling along the coast of south and southeastern China (Fig. 11c). During the break phase, the surface hydrologic forcing was positive $(E-P>0)$ and NMC over the region became negative. The northern SCS region continued to gain moisture (= 3.0 units) from the west, and the warm pool over the SCS was re-established (Fig. 11d). This led to increased CAPE, and recharged the 

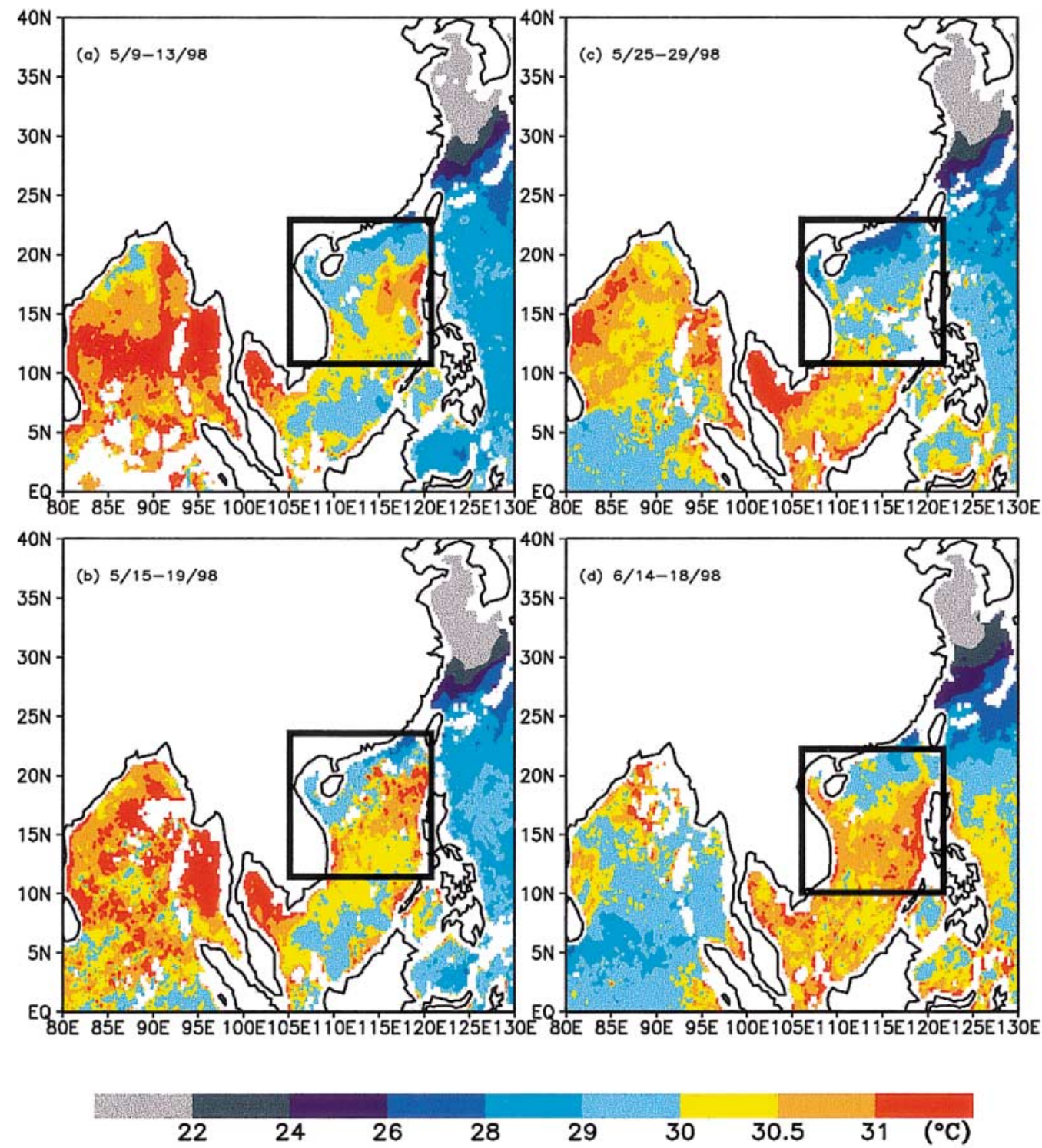

Fig. 11. Sea surface temperature over the Indo-Pacific region during the (a) pre-onset, (b) onset, (c) active and (d) break phases of the SCS monsoon. The northern SCS region is highlight in the rectangular box.

SCS monsoon for a subsequent revival in late June (not shown). Notice that from the onset phase to the break phase, the warm pool had shifted from the Bay of Bengal to the entire SCS. The cooling of the Bay of Bengal was associated with the onset of the Indian monsoon. During the break, precipitation efficiency over the northern SCS dropped substantially to only 47\%. Here the northward moisture transport (=4.3 units) from the northern SCS to south- ern and central China increased substantially, leading to the development of the Mei-yu torrential rainfall over the YRV region.

A similar water budget over the YRV (Table $2 \mathrm{~b})$ shows that before onset of torrential rain over the YRV, $E-P$ was relatively small ( $=0.3$ units), indicating predominantly local water recycling. The precipitation efficiency could not be computed for the pre-YRV phase, because of the slightly negative value of $N M C+E$, pos- 
sibly due to the error in the analyzed wind and moisture fields. During the Mei-yu development, the YRV region was a large moisture sink, with a large portion of its moisture convergence coming from the northward water flux from the northern SCS. The YRV precipitation efficiency was found to exceed 100\% slightly. Previous studies have shown that the large scale precipitation efficiency could exceed $100 \%$ in midlatitude mesoscale convection complexes, due to vigorous microphysical processes in the ice-phase processes in deep clouds. (Gamache and Houze 1983; Ferrier et al. 1996; Li et al. 2002).

\section{Conclusion}

In this paper, we have carried out a study of the evolution in the 3-D large-scale circulation, rain and cloud structure, in connection with the fluctuations of the water cycle with respect to different phases of the SCS monsoon. The sequence of events suggested that the SCS summer monsoon onset in 1998 was triggered in part by the southward incursion of the midlatitude frontal system concomitant with the eastward retreat of the western Pacific Subtropical High. The SCS monsoon onset was preceded immediately by the moisture transport associated with development of the Bay of Bengal depression and surface westerlies over Indo-China. The Bay of Bengal depression evolved from a bifurcation of the first seasonal eastward propagating MJO in May, from the western equatorial Indian Ocean into the southern Bay of Bengal. All the above processes appeared to be coupled.

Major structural changes in convection were identified during different phases of the SCS monsoon. In the pre-onset phase, low clouds and rainless conditions prevailed over the northern SCS. During onset and active phases, the vertical structure of hydrometeors as detected by TRMM precipitation radar showed a bimodal distribution, delineating the presence of stratiform rain associated with ice clouds above the freezing level near $5 \mathrm{~km}$, and convective rain in water clouds below it. The strongest SCS convection occurred at the time of the weakest large-scale wind shear in the vertical during the active phase of the SCS monsoon. The vertical structure and proportion of convective and stratiform rains showed simi- larity to extratropical convective systems, confirming the importance of extratropical influences on convection over northern SCS.

Budget calculations showed that variations in the sources and sinks of water are consistent with the large-scale dynamic forcings and SST variations over the SCS, suggesting that the SST over the SCS, especially the northern domain, may regulate monsoon variability through a charge-discharge mechanisms associated with the onset-break cycles of the SCS monsoon. During the pre-onset phase, the northern SCS was a source of moisture to the overlying atmosphere. During the onset phase, moisture was transported across Indo-China from surface westerlies spun up by the Bay of Bengal convection. At the height of the SCS monsoon, the northern SCS became a strong moisture sink $(E-P \ll 0)$. The overlying atmosphere had a very high precipitation efficiency, with nearly $96 \%$ of the available water from moisture convergence and evaporation precipitated as surface rain over the SCS. During the SCS monsoon break, the northern SCS served as a moisture source for the development of Mei-yu, which was responsible for the torrential rain over the YRV in June 1998.

\section{Acknowledgment}

This research is supported by the Tropical Rainfall Measuring Mission (TRMM) of NASA Earth Science Enterprise. Most of the work was carried out while the second author, Dr. X. Li was an employee of Emergent Information Technologies, Inc. Vienna, Virginia. Prof. P.L. Liam provided the Dongsha Island data. Constructive comments from two anonymous reviewers are acknowledged.

\section{References}

Atlas, R., R.N. Hoffman, S.C. Bloom, J.C. Jusem and J. Ardizzone, 1996: A multiyear global surface wind velocity dataset using SSM/I wind observations. Bull. Amer. Meteor. Soc., 77, 869-882.

Chan, J.C.L., Y. Wang and J. Xu, 2000: Dynamic and thermodynamic characteristics associated with the onset of the 1998 South China Sea Summer Monsoon, J. Meteor. Soc. Japan, 78, 367-380.

Chang, C.-P. and G.T. Chen, 1995: Tropical circulations associated with southwest monsoon onset and westerly surges over the South China Sea. Mon. Wea. Rev., 123, 3254-3267. 
Chen, G.T.J. and C.P. Chang, 1980: The structure and vorticity budget of an early summer monsoon trough over South China and Japan. Mon. Wea. Rev., 108, 942-953.

Chen, T.C., M.C. Yen and S.-P. Weng, 2000: Interaction between the summer monsoons of East Asia and the South China Sea: Intraseasonal Monsoon modes. J. Atmos. Sci., 57, 1373-1392. and J.H. Yoon, 2000: Interannual variation in Indo China summer monsoon rainfall: possible mechanism. J. Climate, 13, 1979-1986.

- and J.R. Chen, 1995: An observational study of the South China Sea Monsoon during the 1979 summer-onset and life cycle. Mon. Wea. Rev., 123, 2295-2318

Chu, H.R. and G.T.J. Chen, 1996: Mei-yu frontogensis. J. Atmos. Sci., 52, 2109-2120.

Ding, Y. and Z. Liu, 2001: Onset and the evolution of the summer monsoon over the South China Sea during SCSMEX field experiment in 1998: J. Meteor. Soc. Japan, 79-1B, 255-276.

- and collaborators, 1999: Onset and activities of Asian monsoon and heavy flooding in China in 1998. In Onset and evolution of the South China Sea monsoon and its interaction with the ocean. Eds. Y. Ding and C. Li, 193-199.

Ferrier, B.N.S., J. Simpson and W.K. Tao, 1996: Factors responsible for precipitation efficiencies in midlatitude and tropical squall simulations. Mon. Wea. Rev., 124, 2100-2125.

Gamache, J.F. and R.A. Houze, Jr., 1983: Water budget of a mesoscale convective system in the tropics. J. Atmos. Sci., 40, 1835-1850.

Hsu, H.H. and C.H. Weng, 2001: Northwestward and westward propagation of the intraseasonal oscillation in the western North Pacific during boreal summer: structure and mechanism. J. Climate, 14, 3834-3850.

C.T. Terrg and C.T. Chen, 1999: Evolution of large scale circulation and heating during the first transition of the Asian summer monsoon. J. Climate., 12, 793-810.

Huang, R.-H. and F.Y. Sun, 1992: Impacts of the tropical western Pacific on the East Asian summer monsoon. J. Meteor. Soc. Japan, 70, 243-256.

Johnson, R., P. Ciesielski, J. Knievel and M.D. Parker, 1999: Preliminary results from the South China Sea Monsoon Experiment Sounding Network. Preprints, 23rd Conference on Hurricanes and Tropical Meteorology, Amer. Met. Soc., 11-14, January 1999. Dallas, TX, 969-972.

Kummerow, C. and collaborators, 2000: The status of the Tropical Rainfall Measuring Mission (TRMM) after two years in orbit, J. Appl. Meteor., 39, 1965-1982.
Lau, K.M. and H. Weng, 2000a: Remote forcing of US summertime droughts and floods by the Asian monsoon? GEWEX News, 10, May Issue, $5-6$.

and - 2000b: Teleconnection linking summertime rainfall variability over North America and East Asia. CLIVAR Exchanges, 5, 18-20.

—, T. Nakazawa and C.H. Sui, 1991: Observations of cloud cluster hierarchies over the tropical western Pacific. J. Geophys. Res., Sp. Supplement, 96, 3197-3208.

, Y. Ding, J.T. Wang, R. Johnson, T. Keenan, R. Cifelli, J. Gerlach, O. Thiel, T. Rickenbach, S.C. Tsay, and P. Lin, 1999: A report of the field operations and early results of the South China Sea Monsoon Experiment (SCSMEX). Bull. Amer. Meteor. Soc., 81, 1261-1270.

and L. Peng, 1992: Dynamics of atmospheric teleconnection during the northern summer. $J$. Climate., 5, 140-158.

and S. Yang, 1997: Climatology and Interannual variability of the Southeast Asian summer monsoon. Adv. Atmos. Sci., 14, 141-162.

- , H.T. Wu and S. Yang, 1998: Hydrologic processes associated with the first transition of the Asian summer monsoon: a pilot satellite study. Bull. Amer. Meteor. Soc., 79, 1871-1882.

Li, Chongyin and Qu Xin, 1999: Characteristics of atmospheric circulation associated with summer monsoon onset in the South China Sea. In Onset and evolution of the South China Sea monsoon and its interaction with the ocean. Eds. Y. Ding and C. Li, 200-209.

Li, X., C.H. Sui and K.M. Lau, 2002: Precipitation efficiency in the tropical deep convective regime: A 2-D cloud resolving model study. $J$. Meteor. Soc. Japan., 80, 205-212.

McPhaden, M.J., 1999: Climate oscillationsGenesis and evolution of the 1997-98 El Niño. Science, 283, 950-940.

Nakazawa, T., 1988: Tropical super clusters within intraseasonal variations over the western $\mathrm{Pa}$ cific. J. Meteor. Soc. Japan, 66, 823-839.

Nitta, T., 1987: Convective activities in the tropical western Pacific and their impact on the northern hemisphere summer circulation. J. Meteor. Soc. Japan, 41, 373-390.

Oki, R., Furukawa, K., Shimizu, S., Suzuki, Y., Satoh, S., Hanado, H., Okamoto, K., Nakamura, K., 1998: Preliminary results of TRMM: Part I, a comparison of PR with ground observations, Mar. Technol. Soc. Japan, 32, 13-23.

Takayabu, Y., T. Iguchi, M. Kachi, A. Shibata, and H. Kanzawa, 1999: Abrupt termination of the 1997-98 El Niño in response to a MaddenJulian oscillation. Nature, 402, 279-282. 
Tao, S. and L. Chen, 1987: A review of recent research in the East Asian summer monsoon in China. In Monsoon Meteorology, Eds. C.-P. Chang and T.N. Krishnamurti, Oxford University Press, pp 60-92.
Yuter, S.E. and Houze, R.A., 1995: Three-Dimensional kinematic and microphysical evolution of Florida cumulonimbus. Part II: Frequency distributions of vertical velocity, reflectivity, and differential reflectivity. Mon. Wea. Rev., 123, 1941-1963. 